\title{
HOLE RELAXATION IN LOW-TEMPERATURE-GROWN GaAs
}

\author{
R. Adomavičius ${ }^{\text {a }}$, K. Bertulis ${ }^{\text {a }}$, A. Krotkus ${ }^{a}$, R. Butkus ${ }^{b}$, and V. Sirutkaitis ${ }^{b}$ \\ ${ }^{\text {a }}$ Semiconductor Physics Institute and Joint Optoelectronics Centre, A. Goštauto 11, LT-01108 Vilnius, Lithuania \\ E-mail: ramunas@opel2.pfi.lt \\ ${ }^{\mathrm{b}}$ Vilnius University Laser Research Centre, Sauletekio 10, LT-10223 Vilnius, Lithuania
}

Received 31 October 2004

\begin{abstract}
Hole density relaxation in low-temperature molecular-beam-epitaxy grown GaAs layers was investigated by using $800 \mathrm{~nm}$ wavelength, $100 \mathrm{fs}$ duration laser pulses for the photoexcitation and $9 \mu \mathrm{m}$ wavelength, $150 \mathrm{fs}$ duration mid-infrared pulses for the induced absorption sampling in the layers. Free-hole absorption at this probe wavelength is by an order of magnitude stronger than the free-electron absorption. Hole lifetimes were found to be enhanced by the doping with beryllium and by the thermal annealing of the samples.
\end{abstract}

Keywords: LTG GaAs, pump-and-probe, electron and hole trapping

PACS: $78.47 .+p, 71.55 . E q$

\section{Introduction}

Recently, much attention was paid to the semiconductor materials with ultrashort carrier lifetimes such as, e. g., low-temperature-grown (LTG) GaAs, because these materials have found many unique applications in optoelectronic and photonic devices [1]. For the majority of those applications, the electron and hole trapping times are material parameters of a critical importance. The majority of the experimental techniques employed as yet are sensitive to excess electrons rather than excess holes, therefore, the dynamics of the electron trapping is by far more intensively studied and better understood than the hole trapping dynamics. In LTG GaAs, e. g., this dynamics was documented by investigating photocurrent transients [2], pump-and-probe reflectance [3] and transmittance [4], time-resolved photoluminescence [5], and in optical pump-terahertz radiation probe [6] experiments. The information on the hole trapping processes in LTG GaAs is scarce, although for the devices manufactured from this material, especially for those working at high repetition frequencies, it is as essential as the electron trapping parameters. One solution of this problem is to use twocolour pump-and-probe techniques. In the experiments of that kind performed so far femtosecond laser pulses in the visible range were used for the excitation of the electron-hole pairs whereas near-infrared pulses (NIR) generated by optical parametric oscillator (OPO) were used as the probe [7,8]. In [7], the wavelength of the probe pulses was $1.56 \mu \mathrm{m}$ and their photon energy corresponded to the transitions from the deep donor levels produced in LTG GaAs by the As-antisite defects to the conduction and/or valence bands. Induced absorption or induced bleaching transients observed in such experiments provided with the information on the As-antisite level population rather than on the hole relaxation in the valence band itself. In [8], the dynamics of the population in the light and heavy hole bands has been monitored by using longer probe wavelengths of 3-4 $\mu \mathrm{m}$ corresponding to the hole transitions from these bands to the split-off valence band. The use of the mid-infrared (MIR) radiation for the probing has allowed to efficiently avoiding the electron contribution. However, this approach was never used for the measurement of the hole density decay in materials with ultrafast carrier recombination.

In the present work, we have performed timeresolved two-colour transmittance measurements on the number of LTG GaAs samples prepared under various technological conditions. Hole trapping time was determined by photoexciting the carriers with nearinfrared $800 \mathrm{~nm}$ pulses and probing the intervalence band transitions with $9 \mu \mathrm{m}$ wavelength optical pulses. This wavelength corresponds to the resonance transitions between the heavy and light hole valence bands (Fig. 1). The clear advantage of this scheme is that resonant interband hole absorption at this wavelength is an order of magnitude stronger than the absorption by 


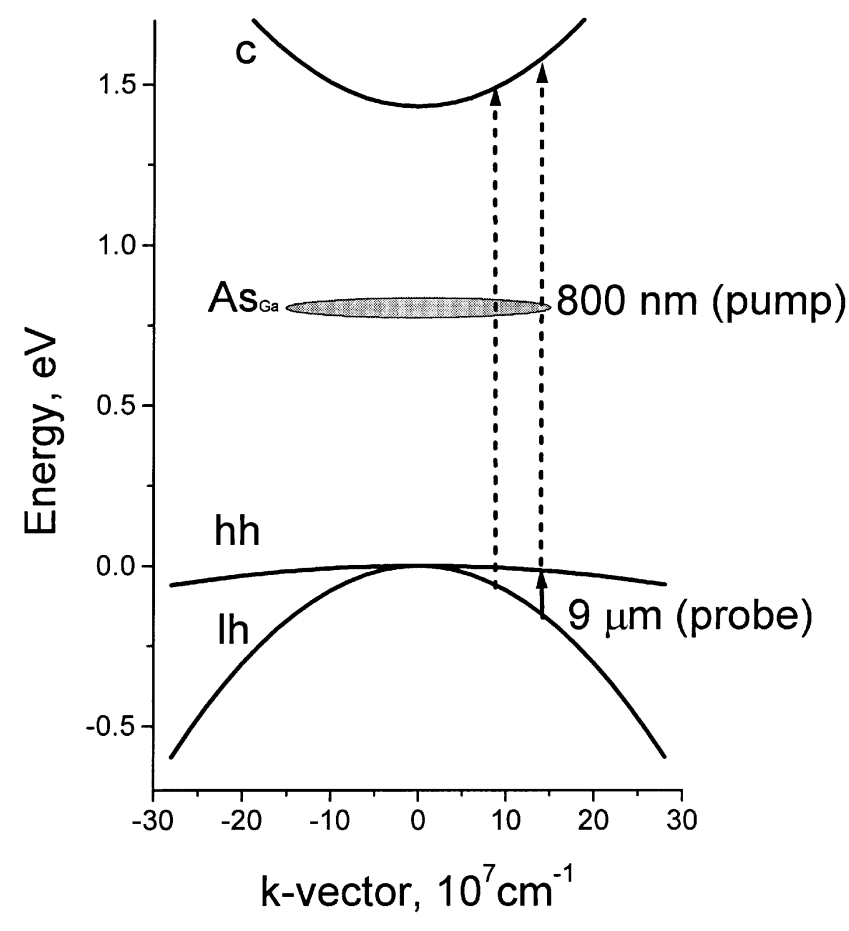

Fig. 1. Energy band diagram of GaAs with indicated pump and probe photon energies.

free electrons [9]. Moreover, MIR quanta are too small to cause electron transitions to and from the deep centres in LTG GaAs, therefore, the hole contribution in measured transients will be prevailing.

\section{Experimental}

Epitaxial LTG GaAs layers were grown on semiinsulating (100)-oriented GaAs substrates in a solid-state molecular beam epitaxy system. An $\mathrm{As}_{4} / \mathrm{Ga}$ beam equivalent pressure ratio of 10 and a growth rate of $1.5 \mu \mathrm{m} / \mathrm{h}$ were used for all growth runs. After standard substrate cleaning from the oxides, a GaAs buffer layer of $500 \mathrm{~nm}$ thickness was grown at $600{ }^{\circ} \mathrm{C}$ substrate temperature, then the growth temperature was lowered down to $270^{\circ} \mathrm{C}$. Some of the samples were doped with $\mathrm{Si}$ or Be during the low-temperature growth; aftergrowth annealing at $600^{\circ} \mathrm{C}$ for $20 \mathrm{~min}$ was applied to part of the samples.

The experimental set-up is shown schematically in Fig. 2. Two-colour pump-and-probe arrangement was based on femtosecond, tunable wavelength laser system available at the Vilnius University Laser Research Centre running at the pulse repetition rate of $1 \mathrm{kHz}$. Electron-hole pairs were generated in the sample by $800 \mathrm{~nm}$ wavelength $100 \mathrm{fs}$ duration pump pulses generated by Ti:sapphire laser and the dynamics of the

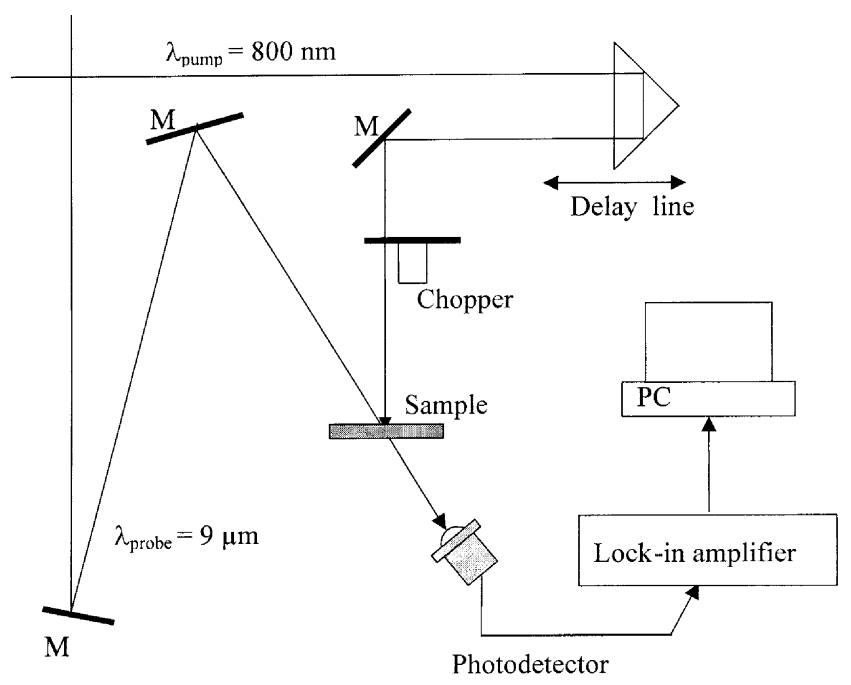

Fig. 2. Experimental set-up.

hole density was monitored by measuring the change in the transmission of $9 \mu \mathrm{m}$ wavelength, 150 fs duration probe pulses from the differential frequency stage of the system. The absorbtion length for the pump wavelength was $0.8 \mu \mathrm{m}$, the thickness of LTG GaAs layer $2 \mu \mathrm{m}$, thus almost all the carriers were generated in the LTG layer. Typical photoexited carrier densities were from $3 \cdot 10^{19} \mathrm{~cm}^{-3}$ to $9 \cdot 10^{19} \mathrm{~cm}^{-3}$. The intensity of the probe beam was measured by means of a pyroelectric detector. Typical probe beam transmittance changes due to the pump pulse were from 20 to $60 \%$.

\section{Results and discussion}

Figure 3 shows the results of two-colour, pump-andprobe measurements obtained on two as-grown LTG GaAs samples: undoped and Be-doped (nominal Be doping density of $1.4 \cdot 10^{20} \mathrm{~cm}^{-3}$ ) samples. Both transients have rise times of approximately $1 \mathrm{ps}$ followed by single-exponential decays with different characteristic time constants. For an as-grown, undoped sample this constant is equal to $1.4 \mathrm{ps}$, whereas Be doping during the growth leads to its increase up to $9 \mathrm{ps}$. It has to be pointed out that the signal rise time is significantly larger than expected from the cross-correlation of the pump and probe laser pulses. Temporal resolution of the experiment is, most probably, reduced by a rather wide probe beam $(\sim 0.3 \mathrm{~mm}$ at the sample), its large incidence to the sample angle $\left(\sim 45^{\circ}\right)$, and the runaway of the pump and probe pulses caused by these two factors. We plan to modify the experimental set-up and to improve its temporal resolution in the nearest future.

Hole capture in LTG GaAs occurs at neutral arsenic antisite $\left(\mathrm{As}_{\mathrm{Ga}}\right)$ defects [10], which are characterized 


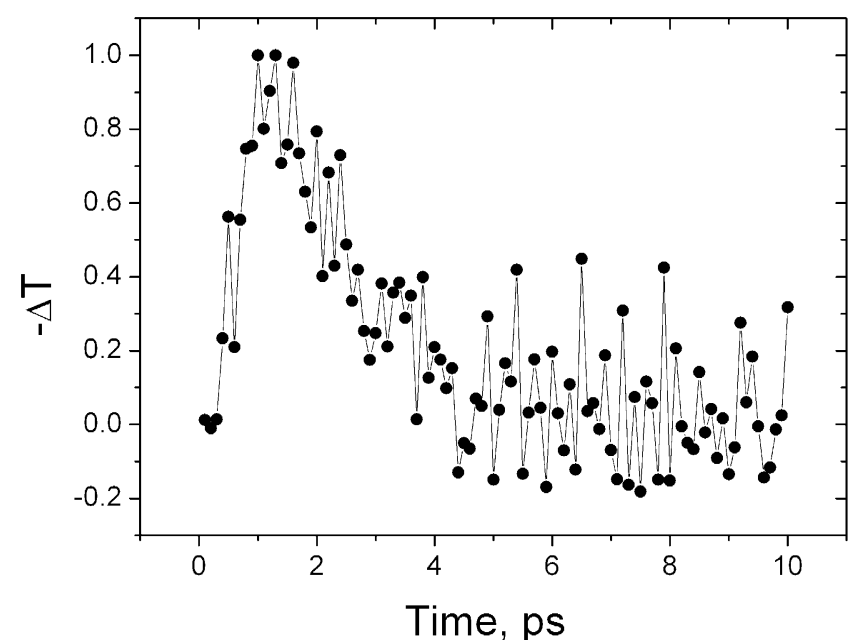

(a)

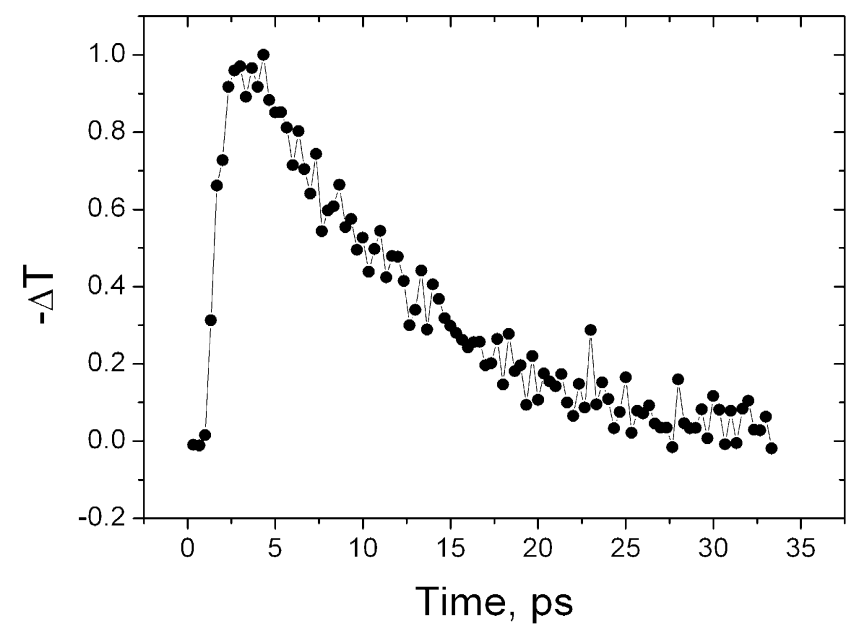

(b)

Fig. 3. Results of two-colour, pump-and-probe measurements performed on (a) as-grown undoped and (b) Be-doped LTG GaAs samples.

by a hole-trapping cross-section of the order of $\sigma_{h}=$ $1.8 \cdot 10^{-15} \mathrm{~cm}^{2}$. Because $\mathrm{As}_{\mathrm{Ga}}$ density in as-grown, undoped LTG GaAs is of the order of $5 \cdot 10^{19} \mathrm{~cm}^{-3}$, this cross-section implies that the hole trapping time should be of the order of $700 \mathrm{fs}$. Therefore, the observed value of $1.4 \mathrm{ps}$ is, most probably, determined by a limited temporal resolution of the experiment. Doping of LTG GaAs during its growth with beryllium, which is an acceptor impurity for GaAs, reduces the number of the hole traps and leads to an increase in the hole trapping time. An opposite effect should have the introduction of $\mathrm{Si}$, which is the main donor in MBE-grown GaAs. We had performed two-colour, pump-and-probe experiments on as-grown, Si-doped LTG GaAs but were not able to observe the transients in MIR beam transmission, most probably, due to a

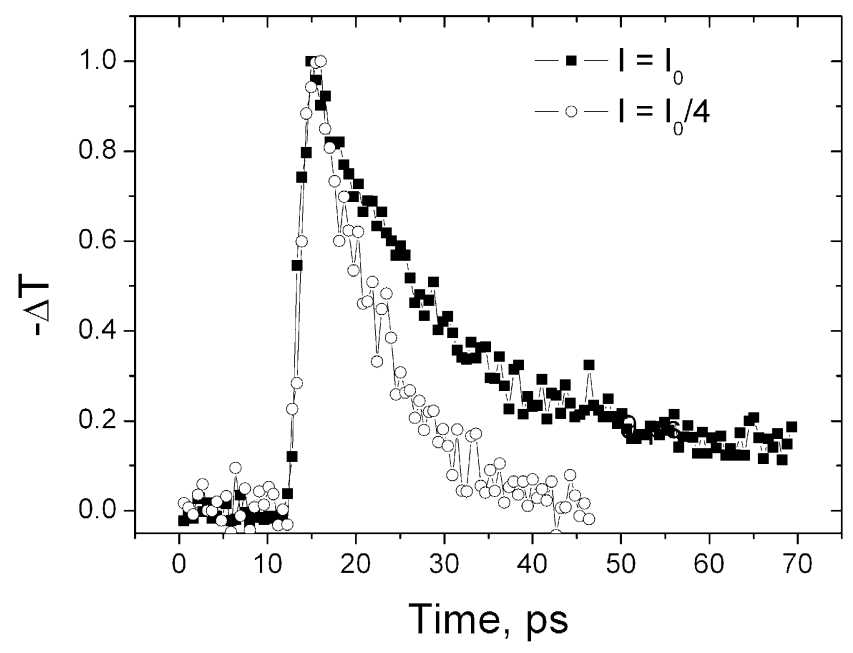

Fig. 4. Results of two-colour, pump-and-probe measurements performed on annealed LTG GaAs sample doped with $N_{\mathrm{Be}}=$ $2 \cdot 10^{17} \mathrm{~cm}^{-3}$.

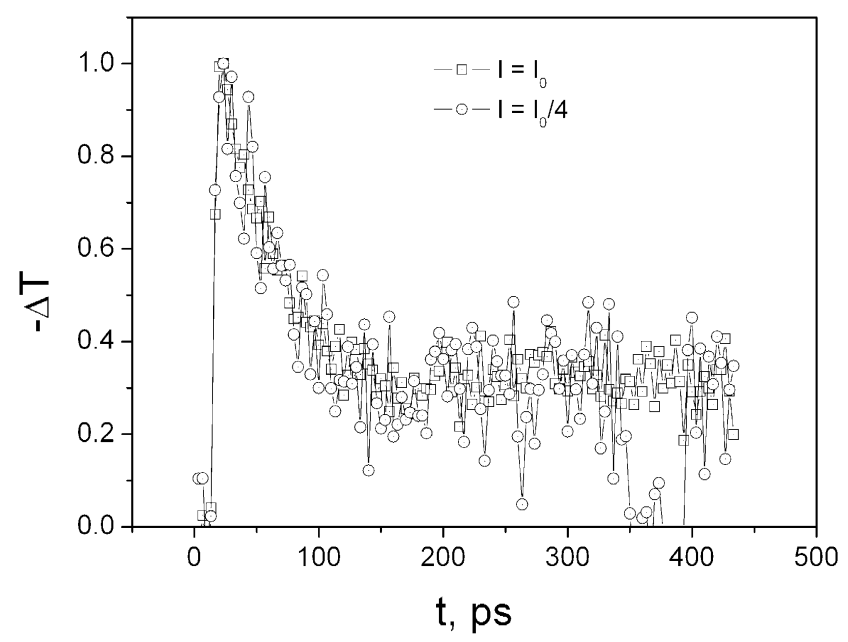

Fig. 5. Results of two-colour, pump-and-probe measurements performed on annealed LTG GaAs sample doped with $N_{\mathrm{Be}}=$ $4 \cdot 10^{19} \mathrm{~cm}^{-3}$.

limited time resolution of the measurement, because in this case the expected hole trapping time should be the shortest.

Transient transmission of MIR pulses was also measured on two annealed LTG GaAs samples doped with $N_{\mathrm{Be}}=2 \cdot 10^{17} \mathrm{~cm}^{-3}$ and $N_{\mathrm{Be}}=4 \cdot 10^{19} \mathrm{~cm}^{-3}$, respectively. Results of these measurements are presented for two pump beam intensities in Figs. 4 and 5. Induced absorption at MIR wavelength decays singleexponentially only in the sample with a lover Be content and at low excitation intensity $I_{0} / 4$ (irradiance $I_{0}$ corresponds to the photoexcited electron-hole pair density of approximately $1 \cdot 10^{19} \mathrm{~cm}^{-3}$ ). The characteristic time of that decay is equal to 9 ps, it increases 
to $\sim 22$ ps when the excitation level becomes larger by a factor of 4 . On the other hand, MIR transmittance transients measured on a sample with a larger Be content do not change with the excitation level of this range. Transients measured at $I_{0}$ and $I_{0} / 4$ have a faster initial decay part (characteristic time of $50 \mathrm{ps}$ ) and a tail corresponding to $30 \%$ of the initial induced signal amplitude, which does not change noticeably over 400 ps time window used in the experiments.

Majority of these observations can be qualitatively explained in terms of the photoexcited electron and hole dynamics caused by a single recombination centre at the middle of the bandgap (As-antisite) and by a shallow hole trap (most probably, Be-level). In annealed sample with $N_{\mathrm{Be}}=2 \cdot 10^{17} \mathrm{~cm}^{-3}$ the density of the ionized $\mathrm{As}_{\mathrm{Ga}}$ is of the order of $4 \cdot 10^{17} \mathrm{~cm}^{-3}$ [10] and the total $\mathrm{As}_{\mathrm{Ga}}$ density is approximately one order of magnitude larger [11]. Because the electron-trapping cross-section at ionized $\mathrm{As}_{\mathrm{Ga}}$ centres is two orders of magnitude larger than the cross-section for holes, the electron traps will be saturated and all As-antisites will be effectively capturing the holes. For the excitation pulse intensity of $I_{0} / 4$ the number of photoexcited carriers $\left(2.5 \cdot 10^{18} \mathrm{~cm}^{-3}\right)$ does not exceed the density of the recombination centres, therefore, the hole lifetime evaluated from the value of $\sigma_{h}$ mentioned before $(8.2 \mathrm{ps})$ correlates well with the lifetime determined experimentally ( $9 \mathrm{ps})$. This is not true at four times larger excitations, when the carrier densities become larger than the concentration of the recombination centres and their lifetime starts to increase.

In an annealed sample with $N_{\mathrm{Be}}=4 \cdot 10^{19} \mathrm{~cm}^{-3}$, the photoexcited carrier density under our experimental conditions is always larger than the number of the hole traps, because Be-doping leads to the reduction of As-antisite density in LTG GaAs [12]. Therefore, initial relaxation of the hole density becomes slower. Moreover, the number of shallow hole traps becomes comparable or even larger than the density of As-antisites, therefore, they should influence the photoexcited carrier dynamics considerably. Part of the photoexcited holes are rapidly captured by shallow traps and much more slowly excited back to the valence band later, which leads to the appearance of long tails in the photoexcited hole density transients. This rapid initial capture is not resolved in our experiments; as an indirect proof of it could be the fact that the magnitude of the MIR transmittance modulation in a heavily Bedoped sample was more than 2 times smaller as in the weakly doped sample.

\section{Conclusions}

In conclusion, we have developed a new two-colour, pump-and-probe technique for ultrafast measurements of the photoexcited hole density relaxation in GaAs and have used this technique for determining hole lifetimes in several LTG GaAs samples prepared under different technological conditions. The results of the experiments were explained in terms of the electron and hole capture at deep arsenic antisite donor defects and shallow Be-impurity levels.

\section{Acknowledgement}

The work was supported by NATO "Science for Peace" project SfP-977978 (SfP-Terahertz) and by the Lithuanian State Science and Education Foundation.

\section{References}

[1] F.W. Smith, A.R. Calawa, C.L. Chen, M.J. Manfra, and L.J. Mahoney, New MBE buffer used to eliminate backgating in GaAs MESFETs, IEEE Electron Device Lett. 9, 77-79 (1988).

[2] F.W. Smith, H.Q. Lee, V. Diadiuk, M.A. Holis, A.R. Calawa, S. Gupta, M. Frankel, D.R. Dykaar, G.A. Mourou, and T.Y. Tsiang, Picosecond GaAsbased photoconductive optoelectronic detectors, Appl. Phys. Lett. 54, 890-892 (1989).

[3] J.F. Roux, J.L. Coutaz, and A. Krotkus, Time-resolved reflectivity characterization of polycrystalline lowtemperature-grown GaAs, Appl. Phys. Lett. 74, 24622464 (1999).

[4] U. Siegner, R. Fluck, G. Zhang, and U. Keller, Ultrafast high-intensity nonlinear absorption dynamics in low-temperature grown gallium arsenide, Appl. Phys. Lett. 69, 2566-2568 (1996).

[5] A. Krotkus, R. Viselga, K. Bertulis, V. Jasutis, S. Marcinkevicius, and U. Olin, Subpicosecond carrier lifetimes in GaAs grown by molecular beam epitaxy at low substrate temperature, Appl. Phys Lett. 66, 1939-1941 (1995).

[6] S.S. Prabhu, S.E. Ralph, M.R. Melloch, and E.S. Harmon, Carrier dynamics of low-temperature-grown GaAs observed via THz spectroscopy, Appl. Phys. Lett. 70, 2419-2421 (1997).

[7] P. Grenier and J.F. Whitaker, Subband gap carrier dynamics in low-temperature-grown GaAs, Appl. Phys. Lett. 70, 1998-2000 (1997).

[8] F. Ganikhanov, K.C. Burr, and C.L. Tang, Ultrafast dynamics of holes in GaAs probed by two-color 
femtosecond spectroscopy, Appl. Phys. Lett. 73, 64-66 (1998).

[9] J.S. Blakemore, Semiconducting and other major properties of gallium arsenide, J. Appl. Phys. 53, R123R181 (1982).

[10] A. Krotkus, K. Bertulis, M. Kaminska, K. Korona, A. Wolos, J. Siegert, S. Marcinkevicius, J.-F. Roux, and J.-L. Coutaz, Be-doped low-temperature-grown GaAs material for optoelectronic switches, IEEE Proc. Optoelectronics 149(3), 111-115 (2002).
[11] X. Liu, A. Prasad, J. Nishio, E.R. Weber, Z. LilientalWeber, and W. Waliukiewicz, Native point defects in low-temperature-grown GaAs, Appl. Phys. Lett. 67, 279-281 (1995).

[12] J.-F. Roux, J.-L. Coutaz, J. Siegert, A. Gaarder, S. Marcinkevicius, A. Wolos, M. Kaminska, R. Adomavicius, K. Bertulis, and A. Krotkus, Electron and hole dynamics in Be-doped low-temperature molecular-beamepitaxy grown GaAs, J. Appl. Phys. (accepted for publication).

\title{
SKYLIŲ RELAKSACIJA ŽEMOJE TEMPERATŪROJE AUGINTAME GALIO ARSENIDE
}

\author{
R. Adomavičius ${ }^{\text {a }}$, K. Bertulis ${ }^{\text {a }}$, A. Krotkus ${ }^{\text {a }}$, R. Butkus ${ }^{b}$, V. Sirutkaitis ${ }^{b}$ \\ ${ }^{a}$ Puslaidininkiu fizikos institutas ir Jungtinis optoelektronikos centras, Vilnius, Lietuva \\ ${ }^{\mathrm{b}}$ Vilniaus universiteto Lazeriniu tyrimu centras, Vilnius, Lietuva
}

\section{Santrauka}

Potencialių taikymų gausa nulèmė intensyvius žemoje temperatūroje auginto GaAs (ŽT GaAs) tyrimus. Viena svarbiausių šios medžiagos savybių - ultrasparti nepusiausvirujų krūvininkų relaksacija - buvo tirta ịvairiais metodais: matuotos fotoliuminescencijos, fotolaidumo, optinio atspindžio ir skaidrio, pralaidumo terahercinei spinduliuotei kinetikos. Buvo nuodugniai ištirtas elektronu pagavimo reiškinys ŽT GaAs. Šiuo metu neblogai žinomos elektronų pagavimo trukmès ir jų priklausomybè nuo ŽT GaAs sluoksnių auginimo salygų, tačiau, kuriant didelio pasikartojimo dažnio prietaisus, taip pat labai svarbios yra skyliu pagavimo bei krūvininku rekombinacijos trukmès. Pirmą kartą išmatuota skylių relaksacija ŽT GaAs. Tiriamasis sluoksnis žadintas $800 \mathrm{~nm}$ bangos ilgio spinduliuotès 100 fs trukmès impulsais. Sugerties pokytis rastas zonduojant $9 \mu \mathrm{m}$ bangos ilgio spinduliuotès 150 fs trukmès impulsais. Šio bangos ilgio spinduliuotei laisvakrūvès sugerties koeficientas skylėms yra maždaug eile didesnis nei elektronams. Ištirta priemaišų įterpimo î sluoksnius ir atkaitinimo įtaka skyliu pagavimo trukmėms. Paaiškejo, kad įterpus berilio priemaišas, trumpinančias elektronų pagavimo trukmes, sulètėja skyliu pagavimas. 